Article

\title{
Czech Journalists' Refreshed Sense of Ethics in the Midst of Media Ownership Turmoil
}

\author{
Roman Hájek *, Sandra Štefaniková, Filip Láb and Alice N. Tejkalová \\ Institute of Communication Studies and Journalism, Faculty of Social Sciences, Charles University in Prague, 11001 \\ Prague, Czech Republic; E-Mails: roman.hajek@fsv.cuni.cz (R.H.), sandra.stefanikova@fsv.cuni.cz (S.Š.), \\ filip.lab@fsv.cuni.cz (F.L.), alice.tejkalova@fsv.cuni.cz (A.N.T.) \\ * Corresponding author
}

Submitted: 31 May 2015 | Accepted: 25 August 2015 | Published: 29 December 2015

\begin{abstract}
In recent years, the Czech Republic has seen the largest changes in media ownership since the early 1990s. Most striking was the purchase of one of the largest publishing houses Mafra by the tycoon Andrej Babiš in June 2013, followed by the takeover of the Czech branch of Ringier by other Czech businessmen later that year. The first case in particular instigated immense discussion about the economic and ethical crisis facing Czech journalism since Babiš is also a powerful political figure (currently the Minister of Finance). In response, a significant number of leading, well-known journalists left media owned by big business and launched projects of quality or "slow" journalism which had until that point been merely discussed theoretically. This paper-based on the results of the Czech part of the Worlds of Journalism Study project-addresses the shift in the ways journalists perceive their roles and ethical responsibilities before and after the 2013 ownership changes. We also present the manner in which these changes are reflected in emerging media projects. It seems that those journalists not affected by the ownership change tend to view journalism ethics and the ability of journalism to exert power more seriously than before.
\end{abstract}

\section{Keywords}

Czech Republic; ethics of journalism; journalism; journalistic roles; ownership change; pressures on journalism

\section{Issue}

This article is part of the special issue "Turbulences of the Central and Eastern European Media", edited by Epp Lauk (University of Jyväskylä, Finland).

(C) 2015 by the authors; licensee Cogitatio (Lisbon, Portugal). This article is licensed under a Creative Commons Attribution 4.0 International License (CC BY).

\section{Introduction}

Speculations that Andrej Babiš, the leader of the political movement ANO 2011 and one of the richest businessmen in the Czech Republic, was interested in purchasing an established publishing house were not rare in 2013. Already in March 2012, Babiš had started his own title 5plus2, a local weekly that quickly spread across the country, becoming the core of the new publishing company AGF Media. From the very beginning, Babiš's activities in the sphere of media were considered part of his broader intention, namely to support his political ambitions. Thus, when it was announced in June 2013 that he had purchased one of the largest media companies Mafra, the publisher of quality newspapers Mladá fronta Dnes and Lidové noviny among others, a wild discussion about the freedom of the press in the Czech Republic broke out. Debate further escalated after the parliamentary elections of that year in which Babiš's party ANO became the second most powerful political party with Babiš himself appointed as the Minister of Finance. According to Darrell West's Global Billionaires Political Power Index (West, 2014), this development made Babiš the 5th most politically powerful billionaire in the world.

With these events, the character of media ownership reached the status of an important public issue. Babiš, however, was neither the first, nor the last 
Czech billionaire to enter media business. In 2008 the coal baron Zdeněk Bakala acquired the publishing house Economia and by 2013 he had also purchased Centrum Holdings, which operates an independent and popular online news daily Aktualne.cz. In November 2013, two Czech electric power billionaires and their financial group J\&T bought the Czech branch of Ringier publishing house, which runs the leading tabloid daily Blesk, for instance. These changes are in line with the general trajectory of the evolution of media ownership in Central and Eastern Europe (CEE). As Štětka (2012) shows, in recent years media companies from CEE have often been taken over by local businessmen who in turn become new media moguls. The entrance of these new players on the media market is closely related to the complicated financial situations of large Western media companies. Many of these companies bought CEE media shortly after the fall of Communist regimes, consolidated them economically and helped promote Western norms of journalism. But with the 2008 economic crisis and consequent declining economic situation of the media, Western owners frequently pulled out of CEE media markets, thereby creating space for new kinds of owners, many of them without clear motivations for the use of media power. These media rearrangements have gradually raised questions about the utilization of news media for political (or other) purposes, or their "Berlusconization" (Wyka, 2007).

In the Czech context, this story of media takeover has additional consequences. After the ownership changes, many journalists decided to leave established newsrooms and start their own projects which promote the values of "quality," "independent" or "slow" journalism. These new projects usually define themselves against media owned by politically motivated businessmen and publically declare their watchdog role and obligation to serve the public (Hájek \& Štefaniková, 2014). It is necessary to add, however, that these new outlets are quite low cost and their impact is rather limited (at least compared to the nationwide dailies). Journalists involved in these projects also lack the security and background of large media companies, which is the downside of their freedom (Hájek, 2014). Regardless, we may suppose changes within the media market have given rise to changes within the journalistic profession.

Currently (September 2015), the most powerful media companies (concerning cross media ownership) in the Czech Republic include Mafra and Empresa Media. Mafra is owned by Andrej Babiš's Agrofert Holding and runs nationwide dailies, a chain of regional weekly newspapers, radio stations, online news outlets, a commercial TV station and on-demand online video service. Empresa Media is owned by Jaromír Soukup and China Energy Company Limited, and possesses weeklies, lifestyle magazines, online news outlets, online platforms and commercial TV in its portfolio.
Other influential media groups on the market are the Czech News Center owned by the investing company J\&T (which runs the most read tabloids, the only Czech sports daily, online news outlets, lifestyle and sports magazines, internet TVs) and Economia controlled by another Czech billionaire Zdeněk Bakala (its media outlets include a business daily, online news outlet, weeklies, specialized business and media magazines).

This paper addresses changes in the media market by exploring journalists' attitudes to their profession before and after the major takeover of Czech media by new owners in 2013. The aim of the research is to show to what extent the ownership change has influenced the character of journalistic work and its perception. Further, using the survey data from the Czech part of the international research project Worlds of Journalism Study, it investigates whether there are any significant differences in this regard between those who were personally affected by the ownership change and those who were not.

\section{Owners' Influence on the Media}

There is no doubt that the type of media ownership influences at least to a certain extent the daily work of journalists as well as their outcomes. The trajectory may not be as straightforward as Herbert Altschull (1995) once suggested in his second law of journalism which states that "the content of the news media always reflects the interests of those who finance the press system." (Altschull 1995, p. 440) However, media ownership underlies many of the internal and external factors and influences that shape the working conditions of journalists in particular and the journalistic profession in general (Hanitzsch et al., 2010; Hanusch, 2009; McManus, 1994).

With regards to the working conditions of journalists, studies have argued that media owners do not directly influence conditions and do not interfere with daily editorial operations (Lukes, 1974). On the other hand, there could be a significant amount of subtle and indirect ways owners control and direct the orientation of news media in favor of their own and affiliated interests, such as by changing work organization, replacing senior and middle management, or increasing emphasis on the efficiency of media production (McNair, 1998). In his recent analysis of over 200 news media from 32 countries, Hanretty (2014) shows the control of editorial mechanisms and freedom is much stronger in the case of news media owned by local owners when compared with media that are part of ownership groups that own multiple outlets in the same media market. He emphasizes the possible advantages of international ownership groups, which are less vulnerable to political pressures than those with local owners. This is of special importance in the context of CEE countries. The departure of Western owners from the 
Central and Eastern European media market, recent research stresses, has changed the operation of news media and the structure of editors and working routines, thereby possibly influencing the quality of the outlets' production (Hume, 2011; Štětka, 2013, 2015).

When evaluating the consequences of change in media ownership, we should also bear in mind repercussions extend beyond the media affected by the change, especially in the case of large media companies. Since media outlets operate in a highly competitive market and emphasize the efficiency of media production, they tend to respond quickly to any shift in the market. Thus, once one outlet changes its policy, its effect can indirectly be felt and adapted to by others, or to put it differently, the change of one title's journalistic milieu (Hanitzsch, 2011) may change the milieu of all journalistic corps. There is now evidence from several countries that the gradually more competitive environment has led to increasing tabloidization (Cashin, 2004; Esser, 1999; Štětka, 2013), automatization, preference for popular soft news referring to celebrities and a decrease in quality of news production (Bantz, 1997; McManus, 1994). In such conditions, serious political and economic issues are slowly vanishing, especially from the online news (Dragomir, 2003; Volek, 2011). Journalistic professionalism is also undermined since the media favor inexperienced and thus cheaper journalists and amateurs instead of experienced professionals (Sasinska-Klas, 1994). In CEE countries, which have always faced economic struggles due to relatively small markets, this development is even more evident and its consequences more threatening to the quality of journalism (Štětka, 2013).

\section{Conditions of Czech Journalism}

Although the fall of Communism in the Czech Republic in 1989 is usually called the Velvet revolution, as Jirák and Köpplová (2012) argue, the transformation of the media system and journalism was rather evolutionary. Certainly many journalists, especially those in high positions, were forced to leave the profession, often replaced by workers with only limited (or even no) journalistic experience and education. However, for quite a long time these "new" people worked in "old" law, economic and mental structures which changed quite slowly. For instance, the detachment of journalists from political power that is considered one of the key journalistic norms was not applied in the first years of democracy since journalists and politicians thought they both were participating in transformative processes (Hájek, Vávra, \& Svobodová, 2015). Later on, many of these practices, performances and norms changed but to a large extent the development of media and journalism in this early democratic stage formed the profession up until now.

One feature of Czech journalism that has its roots in this time is a lack of professionalism. In the early 1990s many people with no education in journalism or communication entered the field and despite this they often gained respect by reporting on the important milestones of the transformation of the country. This contributed to the shared opinion that journalistic education provides no additional value for those who would like to work in media (see Volek \& Jirák, 2006). Even a recent study (Tejkalová \& Láb, 2011) shows that a large number of journalists still have education in areas other than journalism.

Low professionalism is perpetuated by the position of the professional journalistic organization. In the 1990s, the Syndicate of Czech Journalists was established on the grounds of the previous journalistic unions. Nonetheless, the position of the Syndicate is very weak. The majority of Czech journalists have never joined it, and its position has not been respected by journalists, and therefore nor by society (Moravec, 2009).

As Hallin and Mancini (2004) argue, the relatively low level of journalistic professionalism undermines the autonomy of journalists and makes them more vulnerable to external influences. Professional autonomy may also be negatively influenced by corporate and commercial pressures (Hanitzsch \& Mellado, 2011). Economic pressures among others were perceived by Czech journalists as the most important for their work at least at the beginning of the $21^{\text {st }}$ century (Metyková \& Císařová, 2009), whereas the realm of politics seemed to be less important for them. In the context of recent media acquisitions, however, the interconnection of political, economic and media power in the case of Babiš may change the situation.

Another feature of Czech journalists is their low level of self-identification with the profession. The Western model of watchdog or advocacy journalism is not as firm a part of journalistic identity as in Western countries (Volek, 2010). Moreover, many journalists view their job as only a kind of intermezzo in their further careers (Volek \& Jirák, 2006). For example, a considerable number of well-known journalists have entered politics and are keeping important posts in state administration. Czech journalists routinely cultivate good relationships with state-political, executive and police-representatives. This mutually advantageous cooperation offers reporters access to exclusive material, while at the same time guarantees visibility of certain actors or topics in the news media (Jirák \& Trampota, 2008; Metyková \& Císařová, 2009; see also Volek, 2010).

\section{Research Questions and Hypotheses}

The aim of this paper is to explore whether the takeover of several influential Czech media in 2013 has had consequences for the working conditions of Czech journalists and their perception of the journalistic pro- 
fession. We thus focus on three research questions:

RQ1: How have journalists' working conditions differed after the media ownership change? RQ2: How have journalists perceived changes in their roles?

RQ3: How have pressures on journalists' work changed?

To answer these questions we use data collected in the Czech Republic within the larger framework of the collaborative and cross-national research project Worlds of Journalism study (details described below). The survey was conducted in two phases with a year between them. The most important media ownership change (Babiš's acquisition) took place exactly in the middle of the period between the first and second phase of data gathering, the other change following a few months later (still before the second phase of interviews). We thus could trace the transformation of journalists' working conditions and perceptions at the time it was happening. Based on previous research on owner's influence on media and the development of Czech journalism in the post-1989 period, we propose the following hypotheses. For all of them, we expect certain differences between the titles affected and not affected by the ownership change.

The first hypothesis refers to the tendency of new owners to reduce costs and economize the functioning of their newly acquired titles (Štětka, 2012):

$\mathrm{H} 1$ : The journalists' position in titles affected by the ownership change would become more vulnerable and the amount of their work would increase.

Drawing on Hanretty's (2014) conclusions that family or individual ownership leads to stricter control of newsrooms and lower journalistic autonomy, we suppose a similar development in a Czech context:

$\mathrm{H} 2$ : The autonomy of journalists in titles affected by the ownership change regarding the issues they work on would decrease.

Finally, based on the development of the Czech media system after the ownership changes and the proclaimed journalistic values of the newly established journalistic projects, we expect shifts in journalists' perceptions of their roles and working conditions:

H3: After the ownership change, the journalists from titles not affected by it would start to stress the active and critical role of journalism more. $\mathrm{H} 4$ : After the ownership change, the journalists from titles affected by it would perceive external influences on journalism as more important than before.
H5: After the ownership change, the journalists from titles not affected by it would perceive development tendencies in Czech journalism more negatively than those affected by the change.

\section{Methodology}

The analysis uses survey data gathered for the Czech part of the international project, Worlds of Journalism Study (WoJ, www.worldsofjournalism.org). The total number of journalists involved in the study reached 291. For the purpose of the project, professional journalists were defined as those who earned at least half their incomes from journalistic activities, either as media employees or as freelancers. A standardized questionnaire based primarily on Likert scales was used, each interview taking from 30 to 45 minutes. More than two thirds of the interviews were conducted face to face, while the remaining third took place via telephone or email.

The Czech part of WoJ was divided in two stages. The first (135 interviews) took place from October 2012 to January 2013, the second from the end of 2013 until March 2014. In both stages, journalists from all ranges of news media (local as well as national, all types of media from television to print) were included. In the period between the two stages, the important ownership changes (in Mafra and Ringier) were complete; therefore, the data reflect the dynamics of journalism transformation at that time. We thus analyze and compare the sample in two parts, the pre-change and post-change period. We further differentiate between journalists from media that underwent ownership changes ( 41 from the pre-change period, 47 from the after-change period) and those that did not (94 from the pre-change period, 109 from the after-change period).

\section{Results}

The objectives of this study were to discover the impact of notable ownership changes in the Czech media market on journalists' working conditions, their perception of their societal roles and their attitudes towards external pressures that shape the professional milieu. For measurement we used independent samples t-test with the significance for the hypotheses determined at $p<0,05$.

H1: The journalists' position in titles affected by the ownership change would become more vulnerable and the amount of their work would increase.

The first hypothesis was based on evidence that new media owners in CEE countries tend to cut down on costs, economize production and direct the media outlet as if it were a normal business to serve the owner's 
purposes with no public accountability (see Štětka, 2012). The Czech case seemed to be similar. Particularly in the example of Mafra publishing house, many journalists publicly expressed their worries about the future of its titles, referring to the plans of the new owner to merge them with his regional titles and thus to reduce the number of journalists working in the company. To test this hypothesis we used a battery of questions focused on the stability of their position (working full-time/part time, permanent/temporary position, having other paid jobs) and the basic characteristics of their work (number of newsrooms they worked for, level of their specialization and number of items produced).

This hypothesis was supported by our research. The ownership change influenced the working conditions of journalists working in titles affected by it. While the number of journalists working in permanent positions only slightly decreased in media untouched by the change, the situation among the employees of media affected by the ownership change differed dramatically. As we can see from Table 1, 51\% of those within the sample working in permanent positions in media that changed owners fell to just $36 \%$ after the change. This is a key factor that raised considerable insecurity among the journalists working for media that changed owners and the additional data only support this tendency.

Many journalists from the media affected by the ownership change started to work for more newsrooms in order to support themselves. Even if they kept their position, they tended to report a steep increase of produced or edited items per week. Moreover, while we can find that among journalists untouched by the ownership change there was a trend towards specialization, those affected by the change had to work on more topics than before.
H2: The autonomy of journalists regarding the issues they work on would decrease in the titles affected by ownership change.

In this hypothesis we focused on the level of personal autonomy of the journalists in their newsroom, which we presumed would decrease in the titles affected by ownership change. In addition to the evidence from literature (Hanretty, 2014), a wide discussion in the Czech Republic centered on Andrej Babiš's treatment of his new titles. Concerns about Babišs's direct influences on content and editorial decisions contributed to the presumption that journalists working in his titles would have diminished autonomy. In our questionnaire we asked the journalists about their perceived level of personal autonomy to select their stories and to process them according to their preferences, expecting both of them to decrease.

However, as we can clearly see from Table 2, Hypothesis 2 was not supported within our sample. The autonomy of journalists regarding the topic and the form of issues they worked on did not decrease in the titles affected by ownership change and media untouched by the ownership change remained at a similar level. Thus the general perception (but not supported by any data) of decreasing autonomy expressed within discussions of Czech media professionals especially on social networking sites does not match the actual perception of the journalists themselves. This may have been caused by an unwillingness of the journalists affected by the ownership change to respond negatively on this topic (although they were guaranteed anonymity). Also, the time between the ownership change and the gathering of our data was rather brief and the changes may not have been as visible at the beginning. Or it is possible that regarding journalists' autonomy, the situation in the media affected by the ownership change is not as bad as portrayed by the other media.

Table 1. The change of general working conditions of journalists before and after the media takeover in 2013.

\begin{tabular}{|c|c|c|c|c|}
\hline & \multicolumn{2}{|c|}{$\begin{array}{l}\text { Journalists working for titles } \\
\text { that did not change owner }\end{array}$} & \multicolumn{2}{|c|}{$\begin{array}{l}\text { Journalists working for titles that } \\
\text { changed owner }\end{array}$} \\
\hline & Before $(n=94)$ & After $(n=109)$ & Before $(n=41)$ & After $(n=47)$ \\
\hline Proportion of journalists working full-time & $79 \%$ & $88 \%$ & $87 \%$ & $89 \%$ \\
\hline $\begin{array}{l}\text { Proportion of journalists working in } \\
\text { permanent positions }\end{array}$ & $64 \%$ & $61 \%$ & $51 \%$ & $36 \%$ \\
\hline $\begin{array}{l}\text { Proportion of journalists performing paid } \\
\text { work other than journalism }\end{array}$ & $32 \%$ & $20 \%$ & $15 \%$ & $21 \%$ \\
\hline $\begin{array}{l}\text { Proportion of journalists working for more } \\
\text { than } 1 \text { newsroom }\end{array}$ & $20 \%$ & $12 \%$ & $15 \%$ & $21 \%$ \\
\hline $\begin{array}{l}\text { Proportion of journalists working on a } \\
\text { specific beat }\end{array}$ & $18 \%$ & $23 \%$ & $37 \%$ & $28 \%$ \\
\hline $\begin{array}{l}\text { Proportion of journalists producing/editing } \\
\text { more than } 5 \text { items weekly }\end{array}$ & $77 \%$ & $51 \%$ & $68 \%$ & $81 \%$ \\
\hline
\end{tabular}


Table 2. Perception of journalistic autonomy before and after the media takeover in 2013 (means, independent samples t-test).

\begin{tabular}{|c|c|c|c|c|c|c|c|c|}
\hline & \multicolumn{4}{|c|}{$\begin{array}{l}\text { Journalists working for titles that } \\
\text { did not change owner }\end{array}$} & \multicolumn{4}{|c|}{$\begin{array}{l}\text { Journalists working for titles that } \\
\text { changed owner }\end{array}$} \\
\hline & \multicolumn{2}{|l|}{ Means } & \multirow[t]{2}{*}{ Sig. } & \multirow{2}{*}{$\begin{array}{l}\text { Std. Error } \\
\text { Difference }\end{array}$} & \multicolumn{2}{|l|}{ Means } & \multirow[t]{2}{*}{ Sig. } & \multirow{2}{*}{$\begin{array}{l}\text { Std. Error } \\
\text { Difference }\end{array}$} \\
\hline & $\begin{array}{l}\text { Before } \\
(n=94)\end{array}$ & $\begin{array}{l}\text { After } \\
\text { (n= 109) }\end{array}$ & & & $\begin{array}{l}\text { Before } \\
(n=41)\end{array}$ & $\begin{array}{l}\text { After } \\
\text { (n=47) }\end{array}$ & & \\
\hline Perceived autonomy in selecting stories & 3,82 & 3,81 & $\mathrm{n} / \mathrm{s}$ & ,131 & 4,07 & 4,13 & $\mathrm{n} / \mathrm{s}$ & 130 \\
\hline $\begin{array}{l}\text { Perceived autonomy in emphasizing } \\
\text { certain aspects of the story }\end{array}$ & 4,04 & 3,84 & $\mathrm{n} / \mathrm{s}$ & ,120 & 4,15 & 4,17 & $n / s$ & 142 \\
\hline \multicolumn{9}{|c|}{ Note: values: 1 = no freedom at all; 5 = complete freedom. } \\
\hline & \multicolumn{4}{|c|}{$\begin{array}{l}\text { Journalists working for titles that } \\
\text { did not change owner }\end{array}$} & \multicolumn{4}{|c|}{$\begin{array}{l}\text { Journalists working for titles that } \\
\text { changed owner }\end{array}$} \\
\hline & \multicolumn{2}{|l|}{ Means } & \multirow[t]{2}{*}{ Sig. } & \multirow{2}{*}{$\begin{array}{l}\text { Std. Error } \\
\text { Difference }\end{array}$} & \multicolumn{2}{|l|}{ Means } & \multirow[t]{2}{*}{ Sig. } & \multirow{2}{*}{$\begin{array}{l}\text { Std. Error } \\
\text { Difference }\end{array}$} \\
\hline & $\begin{array}{l}\text { Before } \\
(n=94)\end{array}$ & $\begin{array}{l}\text { After } \\
\text { ( } n=109)\end{array}$ & & & $\begin{array}{l}\text { Before } \\
(n=41)\end{array}$ & $\begin{array}{l}\text { After } \\
\text { (n=47) }\end{array}$ & & \\
\hline Be a detached observer & 4,39 & 4,60 & $\mathrm{n} / \mathrm{s}$ & 116 & 4,54 & 4,66 & $\mathrm{n} / \mathrm{s}$ & ,136 \\
\hline Monitor and scrutinize political leaders & 3,20 & 3,51 & $\mathrm{n} / \mathrm{s}$ & ,185 & 3,51 & 3,76 & $\mathrm{n} / \mathrm{s}$ & 241 \\
\hline Monitor and scrutinize business & 2,86 & 3.29 & $*$ & 172 & 3,12 & 3,39 & $\mathrm{n} / \mathrm{s}$ & ,250 \\
\hline Set the political agenda & 2,91 & 2,81 & $\mathrm{n} / \mathrm{s}$ & 171 & 2,88 & 3,07 & $\mathrm{n} / \mathrm{s}$ & ,220 \\
\hline Influence public opinion & 2,74 & 2,58 & $\mathrm{n} / \mathrm{s}$ & 176 & 2,68 & 2,48 & $\mathrm{n} / \mathrm{s}$ & ,240 \\
\hline Be an adversary of the government & 1,56 & 1,63 & $\mathrm{n} / \mathrm{s}$ & ,129 & 1,49 & 1,36 & $\mathrm{n} / \mathrm{s}$ &, 165 \\
\hline
\end{tabular}

Note: significance level $* p<, 05$; values: 1 = unimportant; 5 = extremely important.

H3: After the ownership change, the journalists from titles not affected by it would start to stress the active and critical role of journalism more.

Since the majority of new titles established after the 2013 ownership changes clearly endorse an active role of journalism within society and the need to more effectively control the political and business elites of the country, we proposed that a more critical role of journalism would be stressed by those working for media not affected by the change.

As shown in Table 3, Hypothesis 3 was not supported by statistically significant results. Nonetheless, a shift towards higher sensitivity to the increasingly active and more critical role of journalists is visible among the journalists from both media with and without ownership changes. Despite the fact there is little or no statistical significance in the actual data, we can see some interesting tendencies when comparing the situation before and after the ownership changes.

The most significant and only statistically relevant result shown in Table 3 is the perceived journalistic role to monitor and scrutinize business among the journalists from titles which did not change owner. Such a result is not surprising given the climate at the time of our research in which there were large expectations for the future development of the Czech media landscape and heightened concern that the media was slowly losing their watchdog role. Babiš's takeover of Mafra is usually described as a strategic act to support his political as well as business interests. Babiš's alarming concentration of power also raised questions about his business activities, which may be the reason for this result.

Apart from this statistically significant difference, more subtle but still visible shifts concerning other journalistic roles also appear, such as to behave as a detached observer and the commitment to monitor and scrutinize political leaders. These roles were perceived as more important after the change, regardless of the media ownership changes. This was probably caused by the fact that shortly after the changes all journalists were more attentive and sensitive to their roles and aware of future development.

H4: After the ownership change, the journalists from titles affected by it would perceive external influences on journalism as more important than before.

At the same time as the new owners were entering the media market, a wide debate on the increasing role of media owners, politicians, businessmen and other external influences shaping the journalistic profession took place. Therefore, we hypothesized this would be reflected in the data. To test the hypothesis, we used a battery of questions focused on various external influences.

As summarized in Table 4, this hypothesis was not supported within our sample-there is no statistical 
Table 4. Perception of influences on journalism before and after the media takeover in 2013 (means, independent samples t-test).

\begin{tabular}{|c|c|c|c|c|c|c|c|c|}
\hline & \multicolumn{4}{|c|}{$\begin{array}{l}\text { Journalists working for titles that } \\
\text { did not change owner }\end{array}$} & \multicolumn{4}{|c|}{$\begin{array}{l}\text { Journalists working for titles that } \\
\text { changed owner }(n=88)\end{array}$} \\
\hline & \multicolumn{2}{|l|}{ Means } & \multirow[t]{2}{*}{ Sig. } & \multirow{2}{*}{$\begin{array}{l}\text { Std. Error } \\
\text { Difference }\end{array}$} & \multicolumn{2}{|l|}{ Means } & \multirow[t]{2}{*}{ Sig. } & \multirow{2}{*}{$\begin{array}{l}\text { Std. Error } \\
\text { Difference }\end{array}$} \\
\hline & $\begin{array}{l}\text { Before } \\
(n=94)\end{array}$ & $\begin{array}{l}\text { After } \\
(n=109)\end{array}$ & & & $\begin{array}{l}\text { Before } \\
(n=41)\end{array}$ & $\begin{array}{l}\text { After } \\
(n=47)\end{array}$ & & \\
\hline Editorial supervisors and higher editors & 3,52 & 3,65 & $\mathrm{n} / \mathrm{s}$ & 129 & 3,55 & 3,43 & $\mathrm{n} / \mathrm{s}$ & ,231 \\
\hline Managers of the news organization & 2,91 & 3,18 & $\mathrm{n} / \mathrm{s}$ & 146 & 2,88 & 3,15 & $\mathrm{n} / \mathrm{s}$ & ,256 \\
\hline Owners of the news organization & 2,50 & 2,71 & $\mathrm{n} / \mathrm{s}$ & 159 & 2,53 & 2,61 & $\mathrm{n} / \mathrm{s}$ & ,280 \\
\hline Editorial policy & 3,36 & 3,50 & $\mathrm{n} / \mathrm{s}$ & 130 & 3,08 & 3,54 & $\mathrm{n} / \mathrm{s}$ & ,236 \\
\hline Time limits & 3,71 & 3,87 & $\mathrm{n} / \mathrm{s}$ & 120 & 3,73 & 3,70 & $\mathrm{n} / \mathrm{s}$ & ,203 \\
\hline Journalism ethics & 4,32 & 4,50 & $\mathrm{n} / \mathrm{s}$ & ,098 & 4,46 & 4,46 & $\mathrm{n} / \mathrm{s}$ & 167 \\
\hline Media laws and regulation & 3,99 & 3,92 & $\mathrm{n} / \mathrm{s}$ & 132 & 3,93 & 3,73 & $\mathrm{n} / \mathrm{s}$ & ,258 \\
\hline Government officials & 1,56 & 1,58 & $\mathrm{n} / \mathrm{s}$ & 105 & 1,54 & 1,39 & $\mathrm{n} / \mathrm{s}$ & 146 \\
\hline Politicians & 1,85 & 1,86 & $n / s$ & 129 & 1,78 & 1,80 & $\mathrm{n} / \mathrm{s}$ & 219 \\
\hline Business people & 1,60 & 1,69 & $\mathrm{n} / \mathrm{s}$ & ,113 & 1,59 & 1,57 & $\mathrm{n} / \mathrm{s}$ & ,181 \\
\hline
\end{tabular}

Note: values: 1 = not influential; 5 = extremely influential.

Table 5. Perception of the changes in journalism before and after the media takeover in 2013 (means, independent samples t-test).

\begin{tabular}{|c|c|c|c|c|c|c|c|c|}
\hline & \multicolumn{4}{|c|}{$\begin{array}{l}\text { Journalists working for titles that } \\
\text { did not change owner }\end{array}$} & \multicolumn{4}{|c|}{$\begin{array}{l}\text { Journalists working for titles that } \\
\text { changed owner }(n=88)\end{array}$} \\
\hline & \multicolumn{2}{|l|}{ Means } & \multirow[t]{2}{*}{ Sig. } & \multirow{2}{*}{$\begin{array}{l}\text { Std. Error } \\
\text { Difference }\end{array}$} & \multicolumn{2}{|l|}{ Means } & \multirow[t]{2}{*}{ Sig. } & \multirow{2}{*}{$\begin{array}{l}\text { Std. Error } \\
\text { Difference }\end{array}$} \\
\hline & $\begin{array}{l}\text { Before } \\
(n=94)\end{array}$ & $\begin{array}{l}\text { After } \\
(n=109)\end{array}$ & & & $\begin{array}{l}\text { Before } \\
(n=41)\end{array}$ & $\begin{array}{l}\text { After } \\
(n=47)\end{array}$ & & \\
\hline Ethical standards & 2,52 & 2,89 & $* *$ & 120 & 2,59 & 3,06 & $\mathrm{n} / \mathrm{s}$ & ,261 \\
\hline $\begin{array}{l}\text { Journalists' freedom to make editorial } \\
\text { decisions }\end{array}$ & 3,05 & 3,15 & $\mathrm{n} / \mathrm{s}$ & 102 & 3,00 & 3,21 & $\mathrm{n} / \mathrm{s}$ & 199 \\
\hline Credibility of journalism & 2,52 & 2,68 & $\mathrm{n} / \mathrm{s}$ & 116 & 2,57 & 2,66 & $\mathrm{n} / \mathrm{s}$ & 231 \\
\hline Relevance of journalism for society & 3,22 & 3,08 & $\mathrm{n} / \mathrm{s}$ & ,121 & 3,14 & 2,88 & $\mathrm{n} / \mathrm{s}$ & 189 \\
\hline
\end{tabular}

Note: significance level ${ }^{* *} p<0,01$; values: $1=$ decreased a lot; $5=$ increased a lot

significance in the data. The results show little or no difference between the periods or groups of journalists from media that did and did not change owners. The only visible (though not statistically significant) shift is in the perception of the influence of owners and editorial policy by those affected by the ownership change. This is quite understandable since (as we discussed above) the situation after the ownership change was filled with uncertainty and worry of journalists working for the titles with new owners.

H5: After the ownership change, the journalists from titles not affected by it would perceive development tendencies in Czech journalism more negatively than those affected by the change.

Finally, we were interested whether the current turmoil in Czech media somehow affected the way journalists think about their profession in a long-term perspective. Since a large amount of criticism of the current situation has come from the media not affect- ed by the change, we expected that the journalists from these media might perceive the development in a more negative way. Namely, we expected ethical standards, journalists' freedom and the relevance and credibility of journalism to decline.

Data presented in Table 5 suggest more the opposite to be true. Both groups of journalists tend to be optimistic and perceive an increasing journalistic freedom, growing importance of ethical standards and rising credibility of journalism. Only the relevance of journalism is declining in both cases. The role of ethical standards deserves special attention because the difference before and after the ownership change is highly statistically significant in the group of journalists not affected by the change. Overall, the data suggest that the ownership turmoil may not have raised scepticism among journalistic corps but rather awakened an interest in normative values of journalism. Thus the current situation is not merely one-dimensional and despite all the negatives voiced in public debates it may also bring something positive. The emphasis on ethical 
standards in our data, together with a plea for more responsible, organized and professional journalism, which resounds among many Czech journalists, may be a starting point for a new development stage of Czech journalism.

\section{Conclusion}

Journalism is an ever-changing field that continuously adapts to the larger framework of the society it works within. In recent years, one of the most important aspects Czech journalists have faced was a major media ownership change in which influential (mostly printed) media was taken over by Czech businessmen. This development raises many questions about the quality, ethics and responsibility of journalism to its citizens, especially when new owners are more or less clearly involved in politics (e.g. Andrej Babiš). What Czech journalism faces is thus not only a storm on the media market, but also a potentially dangerous merging of political and economic power. During the time this article was written, speculations appeared that Penta, an originally Slovak investment group with a strong position in the Czech Republic, was interested in buying the VItava-Labe-Press group, the last newspaper publishing company owned by a Western consortium on the Czech media market (it owns a network of local dailies entitled Deník). A top manager of Penta distinctly stated their desire for news media in their portfolio stems from the certainty that it would be worse for anyone to "irrationally attack" them (ČT24.cz, 2015). This is just the tip of the iceberg in terms of what is happening now in Czech journalism and doubtless under such conditions the journalistic profession (and its norms and values) is inevitably changing.

Our study examined whether the media takeover affected the working conditions of Czech journalists and their perception of the journalistic profession. Evidence is based on a survey with journalists conducted before and after the most important media ownership changes in the last decade, which took place in 2013. Although the findings do not give a clear answer about the tendencies, they portray quite clearly the instability and uncertainty of Czech journalism.

Regarding our research questions, working conditions seem to be perceived tougher in the titles affected by the ownership change. Rather than specialized in one area, journalists working in titles affected by ownership change are forced to work on more topics. At the same time, they feel insecure about their employment as the number of permanent positions has decreased dramatically. They also often work for more than one newsroom or perform other paid jobs besides journalism to supplement their salaries. On the other hand, the autonomy of journalists or their perception of external influences did not change in a statistically significant way despite the evidence from literature and public discussions concerning this issue. The opposite group of journalists (those not affected by the change) seem to emphasize a more critical role of journalism in society after the ownership change and stress a rising importance within the journalistic role to monitor and scrutinize business. These journalists also tend to perceive an increasing role of ethics and normative standards of journalistic performance in general in Czech conditions.

The data, nonetheless, do not allow us to draw any strong conclusions. It is important to remember that the study is the first large-scale empirical attempt to examine the real impact of media ownership changes on the working conditions of Czech journalists. It also should be pointed out that the original purpose of the Worlds of Journalism research data collection was to map the situation during the years 2012-2014. The fact that between the two stages of data collection the media landscape changed significantly was a fortunate coincidence which this article takes advantage of. An obvious weakness is that the second phase of data collection took place shortly after the ownership changes and thus some changes may not yet have been traceable.

Taking into account the character of our data, what we can come away with is a reminder of the importance of avoiding clear and simplifying conclusions. The current developments in Czech media have raised criticism and can easily lead to negativism and scepticism. However, as the popular idiom suggests, every cloud has a silver lining. In this case, journalists (mostly those not affected by the change) seem to show a refreshed sense of the importance of journalistic ethics. The ownership turmoil thus can also lead to a renewed interest of Czech journalists in the values and sense of their profession as well as their normative role within society. Among mostly negative news this can be good news.

\section{Conflict of interest}

The authors declare that they have no conflicts of interest in the research.

\section{Acknowledgements}

This research was supported by the project SVV IKSŽ FSV UK 260 231. The authors would like to thank all the people involved in gathering data for this research, namely to Kateřina Písačková, Vojtěch Soudný and Veronika Trestrová.

\section{References}

Altschull, H. (1995). Agents of power: The media and public policy. White Plains: Longman.

Bantz, C. (1997). News organizations: Conflict as a craft- 
ed cultural norm. In D. Berkowitz (Ed.), Social meanings of news (pp. 123-137). Thousand Oaks: Sage.

Cashin, A. (2004). Reining in free media. In A. Cashin \& J. Jirsa (Eds.), Thinking together. Proceedings of the IWM junior fellows' conference, winter 2003 (Vol. 16, pp. 1-11). Vienna: IWM Junior Visiting Fellows' Conferences.

ČT24.cz (2015, May 25). Vláda českých podnikatelů nad soukromými médii bude úplná. ČT24.cz. Retrieved from http://www.ceskatelevize.cz/ct24/media-it/312 690-vlada-ceskych-podnikatelu-nad-soukromymimedii-bude-uplna

Dragomir, M. (2003). Fighting legacy: Media reform in post-communist Europe. Washington: The Atlantic Council of United States.

Esser, F. (1999). "Tabloidization" of news. A comparative analysis of Anglo-American and German press journalism. European Journal of Communication, 14(3), 291-324.

Hájek, R. (2014, December 29). Česká žurnalistika hledá nové cesty. European Journalism Observatory. Retrieved from http://cz.ejo-online.eu/3208/svobodatisku/ceska-zurnalistika-hleda-nove-cesty

Hájek, R., \& Štefaniková, S. (2014, September 20). Czech Republic: New owners and newsroom changes. European Journalism Observatory. Retrieved from http://en.ejo.ch/media-politics/media-ownershipnewsroom-change-czech-republic

Hájek, R., Vávra, J., \& Svobodová, T. (2015). Threats to mutual trust: Czech local politicians and local journalists in the era of professional political communication. Medijske Studije, 6(11), 36-50.

Hallin, D. C., \& Mancini, P. (2004). Comparing media systems: Three models of media and politics. Cambridge: Cambridge University Press.

Hanitzsch, T., Anikina, M., Berganza, R., Cangoz, I., Coman, M., Hamada, B., Hanusch, F., Karadjov, C. D., Mellado, C., Moreira, S. V., Mwesige, P. G., Plaisance, P. L., Reich, Z., Seethaler, J., Skewes, E. A., Noor, D. V., Yuen, K. W. (2010). Modeling perceived influences on journalism: Evidence form a cross-national survey of journalists. Journalism \& Mass Communication Quarterly, 87(1), 5-22.

Hanitzsch, T. (2011). Populist disseminators, detached watchdogs, critical change agents and opportunist facilitators: Professional milieus, the journalistic field and autonomy in 18 countries. International Communication Gazette, 73(6), 477-494.

Hanitzsch, T., \& Mellado, V. (2011). What shapes the news around the world? How journalists in 18 countries perceive influences on their work. International Journal of Press/Politics, 16, 404-426.

Hanretty, C. (2014). Media outlets and their moguls: Why concentrated individual or family ownership is bad for editorial independence. European Journal of Communication, 29(3), 335-350.

Hanusch, F. (2009). A product of their culture. Using a value systems approach to understand the work practices of journalists. The International Communication Gazette, 71(7), 613-626.

Hume, E. (2011). Caught in the middle: Central and Eastern European journalism at a crossroads. A report to the Center for International Media Assistance. Center for International Media Assistance. Retrieved from http://cima.ned.org/publications/researchreports/caught-middle-central-and-easterneuropean-journalism-crossroads

Jirák, J., \& Köpplová, B. (2012) Two decades of free media in the Czech Republic: So what? Remarks on the discourse of post-1989 media transformation. In P. Gross \& K. Jakubowicz (Eds), Media transformations in the post-communist world (pp. 183-194). Lanham: Lexington Books.

Jirák, J., \& Trampota, T. (2008). O vztahu médií a politiky v komparativní perspektivě. In D. Hallin \& P. Mancini (Eds.), Systémy médií v postmoderním světě ( $\mathrm{pp} .9$ 23). Prague: Portál.

Lukes, S. (1974). Power: A radical view. London: Macmillan Publishers.

McManus, J. H. (1994). Market-driven journalism: Let the citizen beware? Thousand Oaks: Sage.

McNair, B. (1998). Sociology of journalism. London: Bloomsbury Academic.

Metyková, M., \& Císařová, L. (2009). Changing journalistic practices in Eastern Europe: The cases of Czech Republic, Hungary and Slovakia. Journalism, 10(5), 719-736.

Moravec, V. (2009) Samoregulace žurnalistiky v České republice po roce 1989 jako součást mediálního systému. In T. Trampota (Ed.), Česká media a Evropská unie: 20 let smazávání hranic (pp. 127-157). Prague: Metropolitní univerzita Praha.

Sasinska-Klas, T. (1994). The transition of mass media in Poland: The road to liberalization. The Electronic Journal of Communication, 4(1).

Štětka, V. (2012). From multinationals to business tycoons: Media ownership and journalistic autonomy in Central and Eastern Europe. The International Journal of Press/Politics, 17(4), 433-456.

Štětka, V. (2013). Media ownership and commercial pressure. Media and Democracy in Central and Eastern Europe. Retrieved from http://mde.politics.ox. ac.uk/images/Final_reports/stetka_2013_final\%20re port_posted.pdf

Štětka, V. (2015). The rise of oligarchs as media owners. In J. Zielonka (Ed.), Media and politics in new democracies: Europe in a comparative perspective (pp. 8598). Oxford: Oxford University Press.

Tejkalová, A., \& Láb, F. (2011). The relationship between journalism studies and media professionals in the Czech Republic. Otázky žurnalistiky, 54(1/2), 35-45.

Volek, J. (2010). Czech journalists after the collapse of the old media system: Looking for new professional self-image. In B. Dobek-Ostrowska, M. Głowacki, K. 
Jakubowicz, \& M. Sükösd (Eds), Comparative media systems. European and global perspectives (pp. 171194). Budapest: Central European University Press.

Volek, J. (2011). Between quality and tabloid press strategies: Czech journalism 20 years after the collapse of the centralised non-market media system. In B. Dobek-Ostrowska \& M. Głowacki (Eds.), Making democracy in 20 years: Media and politics in Central and Eastern Europe (pp. 249-271). Wroclaw: Wydawnictwo Uniwersytetu Wrocławskiego.

Volek, J., \& Jirák, J. (2006). Vybrané atributy profesního sebepojetí českých novinářů. Mediální studia, 1(1),
21-38.

West, D. M. (2014, September 15). Global Billionaires Political Power Index. Brookings. Retrieved from http://www.brookings.edu/research/interactives/20 14/billionaires-global-political-power-index

Wyka, A. W. (2007). Berlusconization of the mass media in East Central Europe: The new danger of italianization. In Third Annual Conference Idea Exchange: Mediums and Methods of Communication in Eastern Europe, Russia, and Central Asia. University of Pittsburgh, USA. Retrieved from http://www. kakanien-revisited.at/beitr/emerg/AWyka1.pdf

\section{About the Authors}

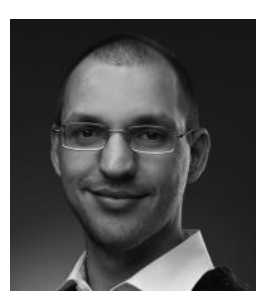

\section{Roman Hájek}

Roman Hájek is a lecturer and PhD student at the Institute of Communication Studies and Journalism, Faculty of Social Sciences, Charles University in Prague. He focuses on journalism studies and political communication. The specific areas on his interests include local journalism and audience perception of politics.

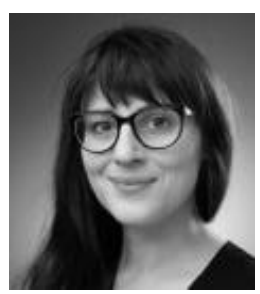

\section{Sandra Štefaniková}

Sandra Štefaniková is a PhD candidate of Media Studies at the Institute of Communication Studies and Journalism, Faculty of Social Sciences, Charles University in Prague. Currently, she is working on her doctorate thesis dealing with the relationship between media, culture, and political authorities in the non-democratic political systems. At the same time, she is working on research concerning the transformation of Czech photojournalism in the last twenty years.

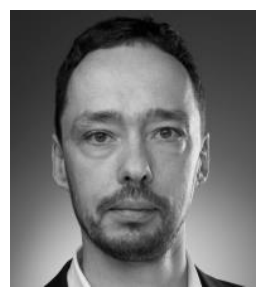

\section{Dr. Filip Láb}

Filip Láb is an associated professor at the Institute of Communication Studies and Journalism, Faculty of Social Sciences, Charles University in Prague. He specializes in visual culture, visual communication, photojournalism, theory and praxis of traditional and digital photography, transition from analogue to digital photography, new functions of visual materials in media.

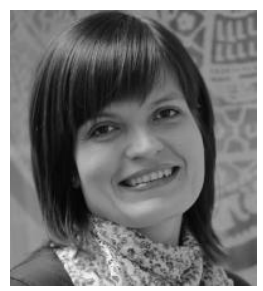

\section{Dr. Alice Němcová Tejkalová}

Alice Němcová Tejkalová is the director of the Institute of Communication Studies and Journalism, Faculty of Social Sciences, Charles University in Prague, and a principal investigator of the Czech part of Worlds of Journalism Study project. Publications include the monograph "The Other Athletes" (2012), the articles "The Undressed Newsroom: The application of visual ethnography in media research" (2014) and "Framing the National Indebtedness" (2013), and the book chapters "Foreign Correspondents in the Czech Republic" (2015), and “Journalist Education and Truth in the Digital Age" (2014). 